\title{
Feeding more than 9 billion by 2050: challenges and opportunities
}

\author{
Richard Strange ${ }^{1}$
}

Published online: 3 April 2015

(C) Springer Science+Business Media Dordrecht and International Society for Plant Pathology 2015

The opinions expressed and arguments employed in this publication are the sole responsibility of the authors and do not necessarily reflect those of the OECD or of the governments of its Member countries.

The event was sponsored by the OECD Co-operative Research Programme on Biological Resource Management for Sustainable Agricultural Systems, whose financial support made it possible for most of the invited speakers to participate in the event.

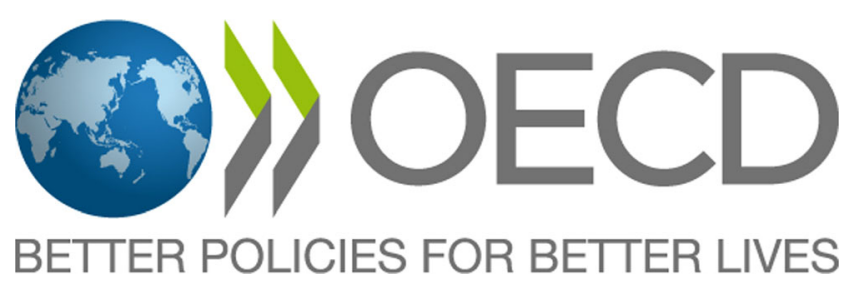

\section{Introducing the Guest Editors of Volume 7(2)}

This issue of Food Security contains papers (with one exception), which arose out of a workshop sponsored by the OECD Co-operative Research Programme on Biological Resource Management for Sustainable Agricultural Systems. I am indebted to the three guest editors whose photographs and biographies appear below for their invaluable help in preparing the papers for publication.

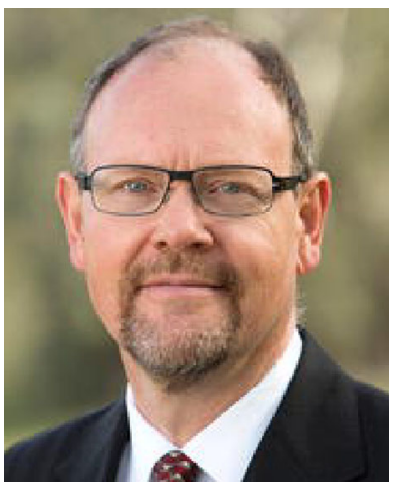

Quentin Grafton is Professor of Economics at the Australian National University (ANU). He is a Fellow of the Academy of Social Sciences of Australia (FASSA) and Chairholder, UNESCO Chair in Water Economics and Transboundary Water Governance. He is the founder of the Global Water Forum (www. globalwaterforum.org), Director of the Food, Energy, Environment and Water Network (www.fe2wnetwork. org/) and Editor in Chief of Policy Forum (www. policyforum.net/). He has served in various policy advisory roles including as the Chair of the Socioeconomics Reference Group for the Murray-Darling Basin Commission (2008-2009) and is currently the Chair of the Marine Estate Expert Knowledge Panel.

Richard Strange

r.strange@sbc.bbk.ac.uk

1 Birkbeck College, University of London, London, UK 


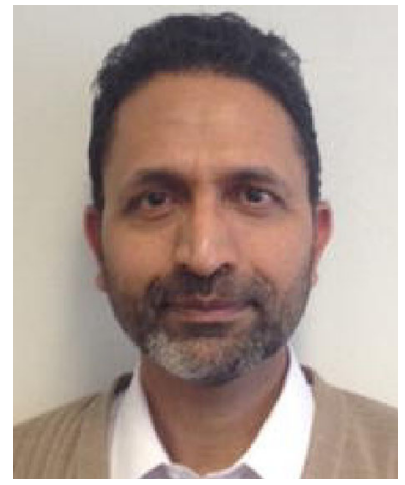

Ejaz Qureshi is Research Program Manager, Agricultural Development Policy, ACIAR, Canberra. Prior to joining ACIAR, he was a Senior Economist and Policy Analyst in CSIRO, Adjunct Fellow at ANU and Principal Research Economist in ABARES also in Canberra. Before moving to Canberra he worked at James Cook University in Townsville. Dr Qureshi has a Masters in AgriEconomic Studies and a Ph.D. in Resource Economics and Environmental Management both from the University of Queensland. He was Associate Editor of the Journal of Hydrology and Guest Editor of the Hydrogeology Journal for its special issue: Economics of Groundwater Management. He has published close to 100 scientific papers including journal articles, book chapters and conference papers.

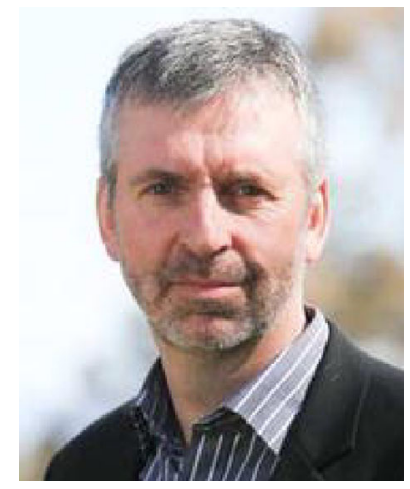

Carsten Daugbjerg is Professor and Director of the Policy and Governance Program, the Crawford School of Public Policy at the Australian National University; and Professor of Agricultural and Food Policy (part-time), the Department of Food and Resource Economics at the University of Copenhagen. His research has focused on agricultural policy reform, the farm trade negotiations in the WTO, private food standards, green taxation, agrienvironmental regulation, organic food policy and biofuels policy. His recent research addresses global food security policy and governance. He has published widely on these issues in international journals and has had four books published. 